\begin{tabular}{|c|c|}
\hline 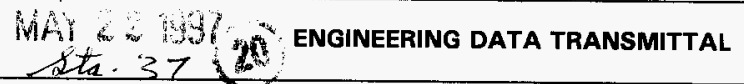 & 1. EDT 619553 \\
\hline
\end{tabular}

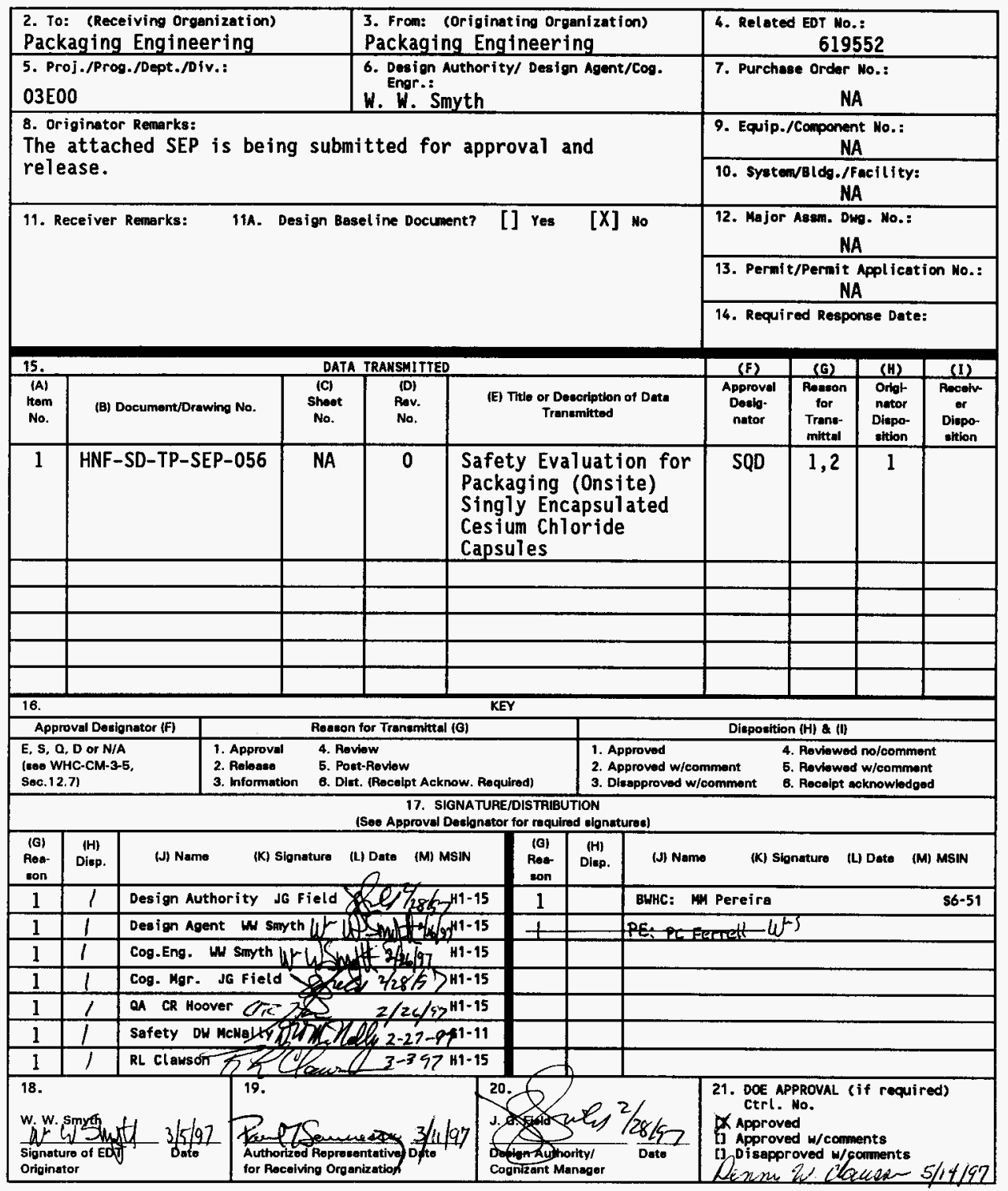

BD-7400 - 172-2 (05/96) GEF097 


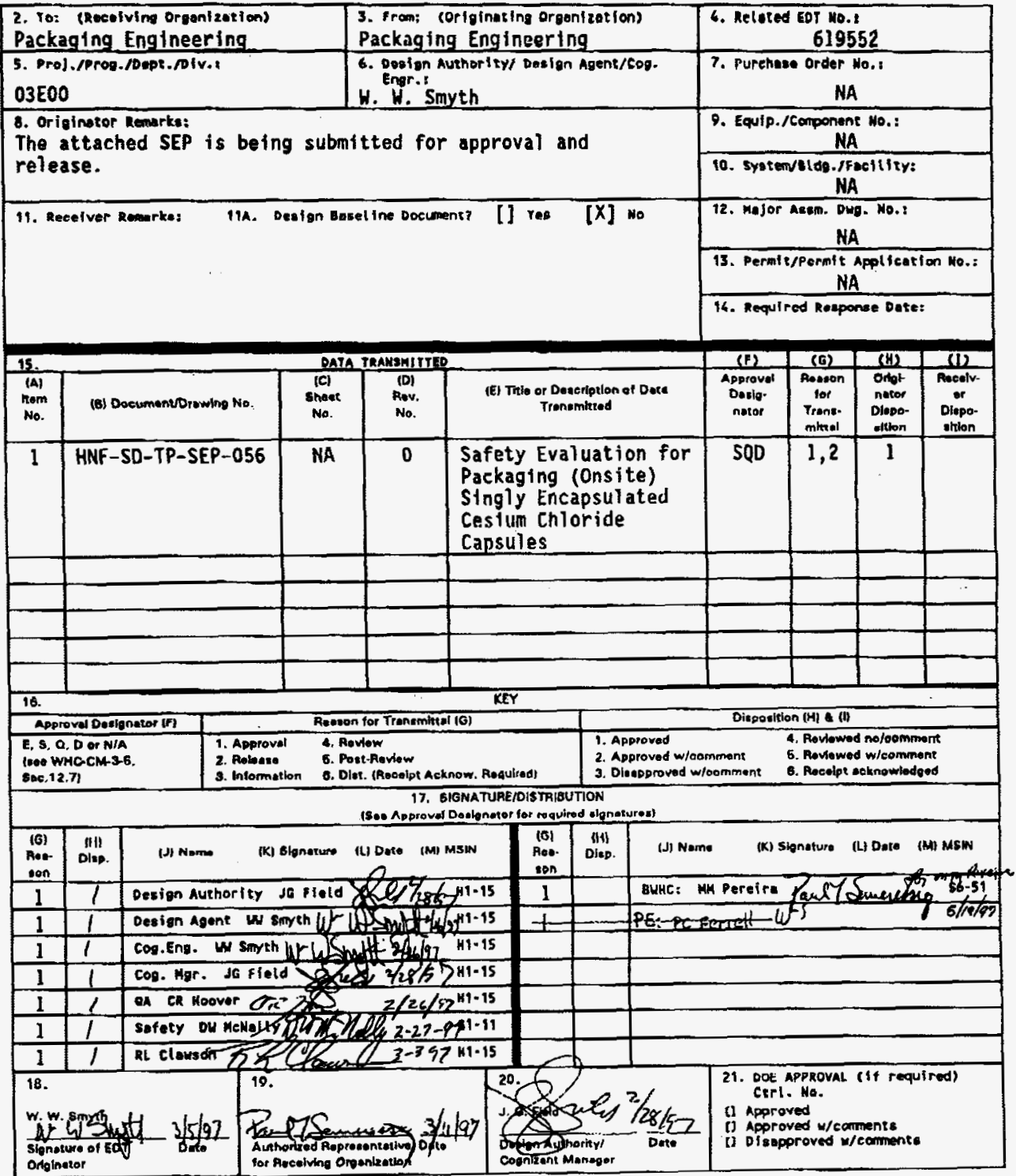




\title{
Safety Evaluation for Packaging (Onsite) Singly Encapsulated Cesium Chloride Capsules
}

\author{
W. W. Smyth
}

Rust Federal Services Inc. Northwest Operations, Richland, WA 99352 U.S. Department of Energy Contract DE-AC06-96RL13200
EDT/ECN: 619553
Org Code: 03E00
UC: 513
B\&R Code: EW7002010
Charge Code: KW64B
Total Pages: -10 ga 19

Key Words: Waste Encapsulation and Storage Facility, overpacked, 324 building

Abstract: Three nonstandard Waste Encapsulation and Storage Facility (WESF) cesium chloride capsules are being shipped from WESF to the 324 building. Normaliy, they would be shipped in the Beneficial Uses Shipping System; however, three capsules are nonstandard. The 3 capsules, along with 13 other capsules, will be overpacked in the 324 building in order to meet the requirements for storage in WESF's pool.

TRADEMARK DISCLAIMER. Reference herein to any specific commercial product, process, or service by trade neme, tradenerk, mamufacturer, or otherwise, does not necessarily constitute or imply Its endorsenent, recommendation, or favoring by the United States Government or any agency thereof or its contractors or subcontractors.

Printed in the United States of America. To obtain copies of this document, contact: HHC/BCS Dociment Control Services, P.O. Box 1970, Mailstop H6-08, Richland WA 99352, Phone (509) 372-2420; Fax (509) 376-4989.
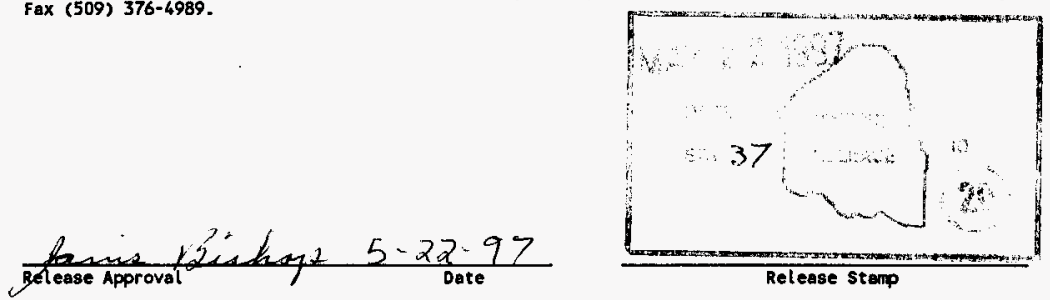

\section{Approved for Public Release}


HNF-SD-TP-SEP-056 ReV. 0

This page intentionally left blank. 
HNF-SD-TP-SEP-056 Rev. 0

CONTENTS

PART A: DESCRIPTION AND OPERATIONS

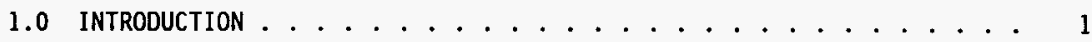

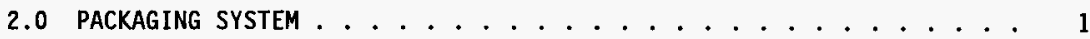

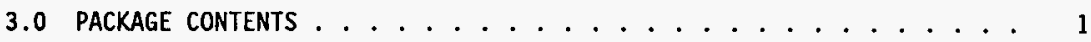

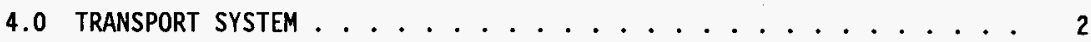

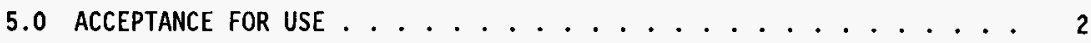

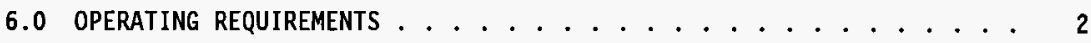

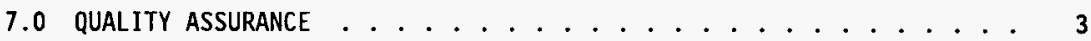

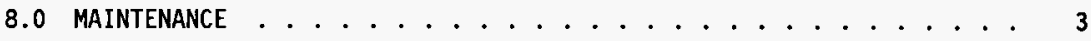

9.0 REFERENCES ..................... 3

\section{PART B: PACKAGE EVALUATION}

1.0 INTRODUCTION 1.1 EVALUATION SUMMARY AND CONCLUSIONS $\ldots \ldots \ldots \ldots \ldots \ldots \ldots$

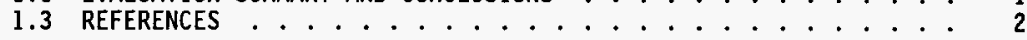

2.0 CONTENTS EVALUATION .......................... 2

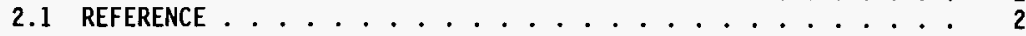

3.0 RADIOLOGICAL RISK EVALUATION .................. 2

3.1 REFERENCES .......................... 4

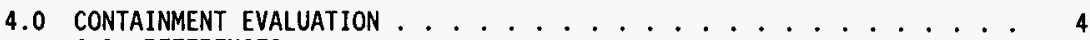

4.1 REFERENCES ...................... 5

5.0 SHIELDING EVALUATION .................. 5

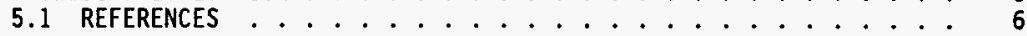

6.0 CRIticality EVAlUAtion . . . . . . . . . . . . . 6

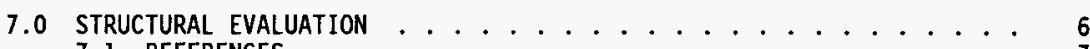
7.1 REFERENCES . . . . . . . . . . . . . . . 7

8.0 THERMal EVAlUation ......................... 7 8.1 REFERENCE ....................... 8 
HNF-SD-TP-SEP-056 Rev. 0

CONTENTS (cont.)

9.0 PRESSURE AND GAS GENERATION .................. 8

9.1 REFERENCE ...................... 8

10.0 TIEDOWN EVALUATION $\ldots \ldots \ldots \ldots . \ldots \ldots$

\section{LIST OF TABLES}

A3-1 Capsules To Be Transported . . . . . . . . . . . . . 1

B5-1 Shielding Results for 16 Cesium Chloride Capsules Totaling $850,000 \mathrm{Ci}$ of ${ }^{137} \mathrm{Cs} \ldots \ldots 66$

B8-1 Cask Temperatures When Loaded With 12 Cesium Chloride Capsules With Total Heat Generation of $4 \mathrm{~kW} \ldots . . . . .8$ 
HNF-SD-TP-SEP-056 Rev. 0

\section{LIST OF TERMS}

$\begin{array}{ll}\text { BUSS } & \text { Beneficial Uses Shipping System } \\ \text { cC-atm/s } & \text { cubic centimeters-atmospheres per second } \\ \text { Ci } & \text { curie } \\ \text { CoC } & \text { certificate of compliance } \\ \text { DOE } & \text { U.S. Department of Energy } \\ \text { HRCQ } & \text { highway route controlled quantity } \\ \text { in. } & \text { inch } \\ \mathrm{ft} / \mathrm{lb} & \text { foot-pound } \\ \mathrm{ft} / \mathrm{s} & \text { feet per second } \\ \mathrm{J} & \text { joule } \\ \mathrm{kg} & \text { kilogram } \\ \mathrm{km} / \mathrm{h} & \text { kilometers per hour } \\ \mathrm{kW} & \text { kilowatt } \\ \mathrm{mi} & \text { mile } \\ \mathrm{mm} & \text { millimeter } \\ \mathrm{mph} & \text { miles per hour } \\ \mathrm{mrem} / \mathrm{h} & \text { millirem per hour } \\ \mathrm{m} / \mathrm{s} & \text { meters per second } \\ \text { SARP } & \text { safety analysis report for packaging } \\ \text { SEP } & \text { safety evaluation for packaging } \\ W & \text { watt } \\ \text { WESF } & \text { Waste Encapsulation and Storage Facility }\end{array}$


HNF-SD-TP-SEP-056 Rev. 0

This page intentionally left blank. 


\section{HNF-SD-TP-SEP-056 Rev, 0 \\ SAFETY EVALUATION FOR PACKAGING (ONSITE) SINGLY \\ ENCAPSULATED CESIUN CHLORIDE CAPSULES}

\section{PART A: PACKAGE DESCRIPTION AND OPERATIONS}

\subsection{INTRODUCTION}

Three nonstandard Waste Encapsulation and Storage Facility (WESF) cesium chloride capsules are being shipped from WESF (225B building) to the 324 building. They would normally be shipped in the Beneficial Uses Shipping System (BUSS) cask under its U.S. Department of Energy (DOE) 1icense (DOE 1996), but these capsules are nonstandard: one has a damaged or defective weld in the outer layer of encapsulation, and two have the outer encapsulation removed. The 3 capsules, along with 13 other capsules, will be overpacked in the 324 building to meet the requirements for storage in WESF's pool.

\subsection{PACKAgING SYSTEM}

The BUSS cask with a 12-capsule basket will be used to transport 3 nonstandard cesium chloride capsules. The BUSS cask is licensed by the DOE to carry up to 16 doubly encapsulated, special form capsules. The safety analys is report for packaging (SARP [SNL 1993]) and license (DOE 1996) allow shipping up to $850,000 \mathrm{Ci}$ of cesium chloride, with a thermal load of 4,000 W.

\subsection{PACKAGE CONTENTS}

Table A3-1 shows the capsules that will be transported.

Table A3-1. Capsules To Be Transported.

\begin{tabular}{|l|l|l|l|}
\hline \multicolumn{1}{|c|}{$\begin{array}{c}\text { Serial } \\
\text { number }\end{array}$} & \multicolumn{1}{|c|}{ Condition } & \multicolumn{1}{c|}{$\begin{array}{c}\text { Est imated activity, } \\
\text { curies }\end{array}$} & \multicolumn{1}{c|}{$\begin{array}{c}\text { Estimated } \\
\text { power, watts }\end{array}$} \\
\hline c-287 & $\begin{array}{l}\text { Outer capsule present, but with visible } \\
\text { weld defect }\end{array}$ & 41,590 & 200 \\
\hline c-596 & outer capsule removed & 36,150 & 174 \\
\hline c-1636 & Outer capsule removed & 38,130 & 183 \\
\hline \multicolumn{2}{r}{ Total } & 115,870 & 557 \\
\hline
\end{tabular}




$$
\text { HNF-SD-TP-SEP-056 Rev. } 0
$$

The BUSS cask SARP (SNL 1993) estimates the total weight of a cask loaded with 16 capsules to be $14,900 \mathrm{~kg}(32,900 \mathrm{1b})$, of which $181 \mathrm{~kg}$ (400 1b) is due to 16 capsules. With 3 capsules instead of 16 , the contents will weigh $34 \mathrm{~kg}$ (75 lb), and the loaded cask will weigh $14,800 \mathrm{~kg}(32,600 \mathrm{lb})$.

The cask is authorized to carry capsules with a total heat load of $4,000 \mathrm{~W}$ and a total activity of 0.85 million $\mathrm{C} i$ of cesium chloride.

\subsection{TRANSPORT SYSTEM}

The BUSS cask, 12-capsule basket, handling fixtures, and its dedicated transport trailer shall be used. All SARP (SNL 1993) requirements for radiation limits and contamination limits shall be adhered to. Since this shipment does not comply with all of the offsite requirements, the roads shall be barricaded during transportation.

\subsection{ACCEPTANCE FOR USE}

A11 maintenance requirements for the BUSS cask shall be performed and documented prior to use.

\subsection{OPERATING REQUIREMENTS}

1. The three capsules shall be cleaned and inspected prior to packaging. Except for the weld defect of the doubly encapsulated capsule, no pits greater than $1 / 16$ in. or weld cracking shall be allowed.

2. The doubly encapsulated capsule shall be tested to show that the inner capsule is free to slide within the outer capsule. If the inner capsule is free to slide, the capsule shall be loaded into the basket according to the SARP (SNL 1993) requirements and normal procedures.

3. The two capsules that have had their outer jackets removed shall be placed into temporary outer jackets to prevent excessive lateral movement during transportation. Caps for the two outer jackets may be placed in the basket before the capsules to prevent excessive movement during normal transportation and to assist in extracting capsules from the basket with a remote manipulator.

4. The three capsules shall be placed symmetrically in the 12-capsule basket, with three empty spaces between the capsules, in order to maintain load balance. 
5. The cask shall be prepared for shipment and operated in accordance with the requirements of Chapter 7, "Operating Procedures, " of the SARP (SNL 1993), when not in conflict with Nos. 1 through 4 of this section.

6. The shipper shall ensure that the transit and wait period from assembly to disassembly of the package shall not exceed 30 days.

7. The BUSS cask shal1 satisfy the requirements of Chapter 8 , "Acceptance Tests and Maintenance Program," in the SARP (SNL 1993).

\subsection{QUALITY ASSURANCE}

A11 quality assurance requirements of the SARP (SNL 1993) shall be followed.

\subsection{MAINTENANCE}

All maintenance required by the SARP (SNL 1993) shall be completed prior to transporting the capsules.

\subsection{REFERENCES}

SNL, 1993, Beneficial Uses Shipping System Cask BUSS Safety Analysis Report for Packaging (SARP), Volumes I and II, SAND83-0698 (TTC-0430), Rev. 4, Sandia National Laboratories, Albuquerque, New Mexico.

DOE, 1996, U.S. Department of Energy Certificate of Compliance For Radioactive Materials Packages, USA/9511/B(U) (DOE), Rev. 3 (August 27), U.S. Department of Energy, EM-76, Germantown, Maryland. 
HNF-SD-TP-SEP-056 Rev. 0

This page intentionally left blank. 
HNF-SD-TP-SEP-056 Rev. 0

PART B: PACKAGE EVALUATION

\subsection{INTRODUCTION}

This safety evaluation for packaging (SEP) demonstrates compliance with the onsite transportation safety program (WHC-CM-2-14, Hazardous Material Packaging and Shipping). The BUSS cask with three nonstandard capsules itemized in Part A, Section 2.0, is shown to meet the acceptance criteria found in the Report on Equivalent Safety for Transportation and Packaging of Radioactive Materials (Mercado 1994).

\subsection{EVALUATYON SUMMARY AND CONCLUSIONS}

This SEP demonstrates safety by comparing this shipment against offsite shipments authorized and conducted according to the safety analysis report for packaging (SARP [SNL 1993]) and the certificate of compliance (CoC

[DOE 1996]). Where there are differences, these differences are evaluated.

The amount of material, in terms of weight, activity, and thermal heat generation, are less than allowed by the CoC. Since this is a highway route controlled quantity (HRCQ), this SEP shall be approved by the U.S. Department of Energy, Richland Operations Office.

The shielding and thermal evaluations show that this shipment will result in radiation dose rates and temperatures significantly lower that those in the SARP (SNL 1993). shipped.

There is no criticality evaluation because no fissile materials are being

The structural adequacy of the shipment depends on the capsules, and the CoC (DOE 1996) requires special form verification within 12 months of shipment. This requirement cannot be met for these three capsules, but the structural evaluation demonstrates that the variance does not cause undue risk.

The radiological risk evaluation presented in Part B, Section 3.0, of this SEP demonstrates that the expected frequency of damage to the cask severe enough to damage the capsules is $1.5 \times 10^{-9}$ per year. Because this is significantly below the site requirement of $10^{-7}$ per year and because the BUSS cask meets onsite transportation safety requirements for shipments of special form cesium chloride capsules, the BUSS cask presents no unacceptable risks to the worker or the public.

Containment is maintained throughout all normal transfer conditions, and the probability of an accident severe enough to cause a release of radioactive materials is so small that a dose consequence analysis is not required. 
HNF-SD-TP-SEP-056 Rev. 0

\subsection{REFERENCES}

DOE, 1996, U.S. Department of Energy Certificate of Compliance For Radioactive Materials Packages, USA/9511/B(U) (DOE), Rev. 3 (August 27), U.S. Department of Energy, EM-76, Germantown, Maryland.

Mercado, J. E., 1994, Report on Equivalent Safety for Transportation and Packaging of Radioactive Materials, WHC-SD-TP-RPT-001, Rev. 0, Westinghouse Hanford Company, Richland, Washington.

SNL, 1993, Beneficial Uses Shipping System Cask BUSS Safety Analysis Report for Packaging (SARP), Volumes I and II, SAND83-0698 (TTC-0430), Rev. 4, Sandia National Laboratories, Albuquerque, New Mexico.

WHC-CM-2-14, Hazardous Material Packaging and Shipping, Westinghouse Hanford Company, Richland, Washington.

\subsection{CONTENTS EVALUATION}

The radioactive contents 1 isted in Part A, Section 3.0, are less than $20 \%$ of the activity approved for transportation in the SARP (SNL 1993). As 1ong as the SARP maintenance and operating requirements are followed, the structural and thermal demands on the cask will be much less than with 16 full-power capsules. The contents are not certified as special form, but the design met the test objectives for special form.

This is an HRCQ because material with activity of greater than $27,000 \mathrm{Ci}$ is being transported.

\subsection{REFERENCE}

SNL, 1993, Beneficial Uses Shipping System Cask BUSS Safety Analysis Report for Packaging (SARP), Volumes I and II, SAND83-0698 (TTC-0430), Rev. 4, Sandia National Laboratories, Albuquerque, New Mexico.

\subsection{RADIOLOGICAL RISK EVALUATION}

The welded stainless steel encapsulation will provide containment for the cesium chloride material as discussed in Part B, Section 4.0. However, as an additional demonstration of safety, a discussion is presented in this section, which addresses the radiological risks associated with the shipment of the BUSS cask containing singly encapsulated cesium chloride capsules.

Onsite transportation safety requirements are out 1 ined in WHC-CM-2-14, Hazardous Material Packaging and Shipping, and Mercado (1994). The acceptability of risks associated with onsite shipments can be determined by a radiological risk evaluation, which applies risk acceptance criteria, cask 
failure threshold values, and Hanford Site truck accident frequencies. A detailed risk analysis is not required, however, as long as a risk evaluation demonstrates that the packaging will prevent release of the contents for any accident that occurs with a frequency greater than $10^{-7}$ per year. An annual release frequency of $10^{-7}$ is the most restrictive acceptance criterion.

The BUSS cask is a certified Type B packaging, which is approved for the shipment of HRCQ nonfissile radioactive material. The BUSS cask provides shielding and additional impact, puncture, and thermal protection for doubly encapsulated special form contents during normal and accident conditions as defined in 10 CFR 71 (January 1, 1993). Compliance with these requirements is documented in the BUSS cask SARP (SNL 1993).

The SARP demonstrates that the cask body, lid, and impact limiters are virtually unaffected by being subjected to the normal and hypothetical accident conditions specified in 10 CFR 71.71 and 10 CFR 71.73. Those conditions include a $9-\mathrm{m}(30-\mathrm{ft})$ drop onto a hard unyielding surface, a puncture test, and immersion in an $800^{\circ} \mathrm{C}$ fire for 30 minutes. The BUSS cask SARP relies on the special form encapsulated materials to provide containment. However, because the BUSS cask structural members withstand hypothetical accident conditions, protection of the payload is also being provided by the BUSS cask body, lid, and impact limiters.

In a radiological risk evaluation the total conditional probability of failure of the packaging is multiplied by the frequency of accidents per year to arrive at an annual accident release frequency. If the annual accident release frequency is below $10^{-7}$ releases per year, the shipment meets onsite transportation safety requirements (Mercado 1994).

The Hanford Site truck accident rate for all trucks, including vans and lightweight pickup trucks, is equal to $2.0 \times 10^{-7}$ accidents per mile (Green et al. 1996). For a shipment of radioactive materials that is carried out by trained truck drivers during daylight hours in good road conditions, a reduction factor of 20 can be applied to lower the rate to $1 \times 10^{-8}$ (H\&R 1995). The BUSS cask will be used for one shipment of $40.2 \mathrm{~km}$ (25 mi), which, when multiplied by the accident rate and reduction factor, gives a frequency of $2.5 \times 10^{-7}$ accidents per year.

The conditional release probabilities are based on the performance of the packaging and are taken from a study performed by Sandia National Laboratory on the response of large casks to severe accidents (Dennis et al. 1976). The BUSS cask is $30 \mathrm{~cm}$ (12 in.) thick, and the probability of a release given a puncture event is approximately equal to zero. The cask will withstand a 30 -minute, $800{ }^{\circ} \mathrm{C}$ fire; therefore, the probability of a fire failure on the Hanford Site, where emergency responders have a 15-minute response time and are trained in the handling of radioactive material, is also approximately zero. In addition, based on the analysis presented in the BUSS cask SARP (SNL 1993), the BUSS cask would not fail from the crush force of the trailer $(7,257 \mathrm{~km}[16,000 \mathrm{lb}])$ should a rollover accident occur. Therefore, the probability of failure from the crush force would al so be approximately equal to zero.

The only conditional release probability that will affect the annual accident release frequency is related to impact. The BUSS cask SARP 
demonstrates that the cask will survive a 9-m (30-ft) drop onto a hard unyielding surface. If it is conservatively assumed that the cask fails a velocity change of $48.3 \mathrm{~km} / \mathrm{h}$ (30 mph) onto concrete, given that the system has a gross vehicle weight of 31.75 metric tons (35 tons), the corresponding total conditional release probability is 0.00612 (Dennis et al. 1976). When multiplied by the annual accident frequency of $2.5 \times 10^{-7}$, the resulting annual accident release frequency is $1.5 \times 10^{-9}$, which is well below the required $10^{-7}$. In fact, 65 shipments can be made in one year and still meet the accident criterion of less than $10^{-7}$. Therefore, the BUSS cask meets onsite transportation safety requirements, and shipments of singly encapsulated cesium chloride capsules in the BUSS cask present no unacceptable risks to the worker or the public.

\subsection{REFERENCES}

10 CFR 71, 1993, "Transportation and Packaging of Radioactive Material," Code of Federal Regulations, as amended.

Dennis, A. W., J. T. Foley, W. F. Hartman, and D. W. Larson, 1978, Severities of Transportation Accidents Involving Large Packages, SAND77-0001, Sandia National Laboratories, Albuquerque, New Mexico.

Green, J. R., B. D. Flanagan, and H. W. Harris, 1996, Hanford Site Truck Accident Rate, 1990-1995, WHC-SD-TP-RPT-021, Rev. 0, Westinghouse Hanford Company, Richland, Washington.

H\&R, 1995, Recommended Onsite Transportation Risk Management Methodology, H\&R522-1, H\&R Technical Associates, Inc., Oak Ridge, Tennessee.

Mercado, J. E., 1994, Report on Equivalent Safety for Transportation and Packaging of Radioactive Materials, WHC-SD-TP-RPT-001, Rev. 0 , Westinghouse Hanford Company, Richland, Washington.

WHC-CM-2-14, Hazardous Material Packaging and Shipping, Westinghouse Hanford Company, Richland, Washington.

\subsection{CONTAINMENT EVALUATION}

The containment boundary for this shipment is the inner capsule, while the SARP evaluation (SNL 1993) assumes doubly contained capsules as the containment. This shipment differs from the SARP analysis only in that the material is singly contained.

The inner capsules were tested after fabrication and were required to demonstrate a leak rate of less than $10^{-8} \mathrm{~atm} \mathrm{cc} / \mathrm{s}$ for acceptance, so they are leaktight (Kenna 1984). Additionally, special form testing was conducted on singly encapsulated as well as doubly encapsulated cesium chloride capsules. The testing included a 10-m drop onto an unyielding surface, immersion in an $815{ }^{\circ} \mathrm{C}$ fire for 30 minutes, and submersion in water for 24 hours. Examination and destructive testing of the capsules showed no leakage or damage that could 
cause loss of contents. The test report concluded that the singly encapsulated cesium chloride was capable of withstanding the special form testing with no loss of contents, but it was not certified as special form (Hammond 1975).

The three capsules being shipped have not undergone extremes in temperature variation suspected in damaging other capsules and are still considered to be leaktight. The two inner capsules will be inspected for evidence of bulging, weld defects, or pits; in the absence of these indications, the capsules can be considered to be resistant to damage likely to be encountered in normal or accident conditions of transportation. Similarly, the degree of weid damage evident in the doubly encapsulated capsule will not prevent the outer encapsulation from protecting the inner capsule during transportation.

The cask seal is designed to have a leak rate no greater than $10^{-4} \mathrm{cc}-a \mathrm{tm} / \mathrm{s}$ and to retain the hel ium coolant during normal transportation. After an accident, the SARP (SNL 1993) demonstrates that there will be no permanent deformation of the cask seal, but no leaktightness was demonstrated because helium did not have to be retained after an accident. Singly encapsulated cesium chloride capsules met special form requirements when they were fabricated and can still be considered leaktight, so the cask is not required to be leaktight.

\subsection{REFERENCES}

Hammond, J. E., 1975, Cesium Chloride Capsule Testing for Special Form Qualification, ARH-CD-440, Atlantic Richfield Hanford Company, Richland, Washington.

Kenna, B. T., 1984, WESF ${ }^{137}$ Cs Gamma Ray Sources, SAND82-1492, Sandia National Laboratories, Albuquerque, New Mexico.

SNL, 1993, Beneficial Uses Shipping System Cask BUSS Safety Analysis Report for Packaging (SARP), Volumes I and II, SAND83-0698 (TTC-0430), Rev. 4, Sandia National Laboratories, Albuquerque, New Mexico.

\subsection{SHIELDING EVALUATION}

This shipment involves less than $3 / 16$ of the radioactive contents evaluated by the SARP (SNL 1993) and allowed by the COC (DOE 1996). With the possible exception of the stainless steel upper cap of the outer encapsulation, all shielding assumed by the SARP analys is is in place. This cap is $1 \mathrm{~cm}(0.4 \mathrm{in.})$ thick and will have a negligible effect on the external dose rate because the bottom of the cask and the 1id are over $30 \mathrm{~cm}(12 \mathrm{in}$.) thick and the amount of cesium chloride being transported will be much less than authorized by the SARP. 
Table 85-1 shows the results from the SARP analysis (SNL 1993).

Table B5-1. Shielding Results for 16 Cesium Chloride Capsules Totaling $850,000 \mathrm{Ci}$ of ${ }^{137} \mathrm{Cs}$.

\begin{tabular}{|l|c|c|c|c|c|c|}
\cline { 2 - 7 } \multicolumn{1}{c|}{} & \multicolumn{4}{c|}{ Normal conditions of transport } & \multicolumn{2}{c|}{ Accident conditions } \\
\cline { 2 - 7 } \multicolumn{1}{c|}{} & \multicolumn{2}{c|}{ Package surface } & $2 \mathrm{~m}$ from surface & \multicolumn{2}{c|}{$1 \mathrm{~m}$ from surface } \\
\cline { 2 - 7 } \multicolumn{1}{c|}{} & Top & Side & Top & Side & Top & Side \\
\hline $\begin{array}{l}\text { Gamma dose } \\
\text { rate, mrem/h }\end{array}$ & 64 & 29 & 2.9 & 1.2 & 11 & 4.6 \\
\hline
\end{tabular}

Source: SNL, 1993, Beneficial Uses Shipping Systen Cask BUSS Safety Analys is Report for Packeging (SARP), volumes I and II, SAND83-0698 (TTC-0430), Rev. 4, Sandia Hational Laboratori es, Albuquerque, New Mexico.

Since $115,870 \mathrm{Ci}$ will be shipped, the lack of a top cap $1 \mathrm{~cm}(0.4 \mathrm{in.})$ thick on two of three capsules will not be significant.

\subsection{REFERENCES}

DOE, 1996, U.S. Department of Energy Certificate of Compliance For Radioactive Materials Packages, USA/951l/B(U) (DOE), Rev. 3 (August 27), U.S. Department of Energy, EM-76, Germantown, Maryland.

SNL, 1993, Beneficial Uses Shipping System Cask BUSS Safety Analysis Report for Packaging (SARP), Volumes I and II, SAND83-0698 (TTC-0430), Rev. 4, Sandia National Laboratories, Albuquerque, New Mexico.

\subsection{CRITICALITY EVALUATION}

No fissile materials are being transported, so no criticality analysis is required.

\subsection{STRUCTURAL EVALUATION}

The SARP (SNL 1993) evaluates the cask as an outer packaging for special form capsules. The record of the qualification of the capsules as special form (Hammond 1975) showed, however, that the inner capsule alone exceeded the requirements for special form material, with no outer encapsulation. With a second encapsulation, the record of qualification simply stated that the capsule ". . far exceeds the requirements to qualify as special form material." 


$$
\text { HNF-SD-TP-SEP-056 Rev. } 0
$$

As a part of the special form testing, the inner capsule was dropped $10 \mathrm{~m}$ (33 ft) onto a test pad. To qualify for special form, the capsule must be dropped $9 \mathrm{~m}(30 \mathrm{ft})$ and retain its contents. The additional $1 \mathrm{~m}$ drop height (additional $3 \mathrm{ft}$ ) resulted in an impact velocity of $14 \mathrm{~m} / \mathrm{s}$ rather that the required $13 \mathrm{~m} / \mathrm{s}(46 \mathrm{ft} / \mathrm{s}$ rather than $44 \mathrm{ft} / \mathrm{s})$. All of the special form test requirements were exceeded during the test.

The SARP (SNL 1993) analyzed the capsule during a 9-m (30-ft) cask drop onto the lid, accounting for a $3.8-\mathrm{cm}(1.5-i n$.$) vertical gap between the outer$ capsule and the lid. When the top impact limiter first strikes a nonyielding surface, the lid begins to decelerate while the capsule is still accelerating downward. When the accelerating capsule impacts the decelerating 1id, the analysis showed that an inner capsule would absorb $209 \mathrm{~J}$ (154 ftelb) of energy. With a temperature of $482{ }^{\circ} \mathrm{C}\left(900^{\circ} \mathrm{F}\right)$, the inner capsule (only the inner capsule was assumed to take load) would experience a vertical deformation of $3.7 \mathrm{~mm}(0.147 \mathrm{in}$.$) , and this amount of plastic deformation$ would not cause failure of the capsule. During the drop test for special form qualification, the inner capsule absorbed $805 \mathrm{~J}$ (594 $\mathrm{ft} \cdot 1 \mathrm{~b})$ of energy without loss of contents.

If the outer jacket's cap is omitted from the shipment, there is an added gap of less than $2.5 \mathrm{~cm}$ ( 1 in.) between the 1 id and capsule. An analysis similar to that done in the SARP (SNL 1993) is not needed, however, since the inner capsule design has already been tested by a $10-\mathrm{m}(33-\mathrm{ft})$ drop onto an unyielding surface. This is a more severe requirement than would be experienced by the capsule during a 9-m $(30-\mathrm{ft})$ drop in the cask with an impact limiter that reduces the deceleration to $105 \mathrm{~g}$.

\subsection{REFERENCES}

DOE, 1996, U.S. Department of Energy Certificate of Compliance For Radioactive Materials Packages, USA/9511/B(U) (DOE), Rev. 3 (August 27),

U.S. Department of Energy, EM-76, Germantown, Maryland.

Hammond, J. E., 1975, Cesium Chloride Capsule Testing for Special Form Qualification, ARH-CD-440, Atlantic Richfield Hanford Company, Richland, Washington.

SNL, 1993, Beneficial Uses Shipping System Cask BUSS Safety Analysis Report for Packaging (SARP), Volumes I and II, SAND83-0698 (TTC-0430), Rev. 4, Sandia National Laboratories, Albuquerque, New Mexico.

\subsection{THERMAL EVALUATION}

Table B8-1 shows the results of the SARP analysis (SNL 1993). The SARP considered both 12- and 16-capsule baskets and found higher temperatures in the 12-capsule case. 
Table B8-1. Cask Temperatures When Loaded With 12 Cesium Chloride Capsules With Total Heat Generation of $4 \mathrm{~kW}$.

\begin{tabular}{|l|l|l|}
\hline \multicolumn{1}{|c|}{ Location } & \multicolumn{1}{|c|}{$\begin{array}{c}\text { Calculated } \\
\text { temperature, } \\
{ }^{\circ} \mathrm{C}\left({ }^{\circ} \mathrm{F}\right)\end{array}$} & \multicolumn{1}{c|}{$\begin{array}{c}\text { Allowable } \\
\text { temperature, } \\
{ }^{\circ} \mathrm{C}\left({ }^{\circ} \mathrm{F}\right)\end{array}$} \\
\hline Cesium chloride & $462(864)$ & $\mathrm{N} / \mathrm{A}$ \\
\hline Inner cladding & $407(765)$ & $450(842)^{\mathrm{a}}$ \\
\hline Outer cladding & $369(696)$ & $800(1472)^{\mathrm{b}}$ \\
\hline Basket & $348(658)$ & $800(1472)$ \\
\hline Lid or port seals & $202(396)$ & $450(842)^{\mathrm{C}}$ \\
\hline Inner cask wall & $202(396)$ & $800(1472)$ \\
\hline Outer cask wall & $140(284)$ & $800(1472)$ \\
\hline
\end{tabular}

Source: SKL, 1903, Beneficial Uses Shipping Sygten Cask BUSS Safety Analysis Report for Packeging (SARP), Votumes I and II, SAHD83-0698 (TTC-0430), Rev. 4 , Sandia National Laboratories, Albuquerque, New Mexico. Inner cladding temperature limit was used since it is the temperature used in testing for long term geologic disposal. Below this temperature, there is no anticipated corrosion of the cladding material. btainless steel temperature limit, other than the inner cladding. was based on reducing the potential for significant corrosion.

"Seal temperature limits are the maximum operating temperatures provided by the manufacturer.

With $557 \mathrm{~W}$ of thermal power instead of 4,000 , the temperatures will be significantly less than those calculated by the SARP (SNL 1993).

\subsection{REFERENCE}

SNL, 1993, Beneficial Uses Shipping System Cask BUSS Safety Analysis Report for Packaging (SARP), Volumes I and II, SAND83-0698 (TTC-0430), Rev. 4, Sandia National Laboratories, Albuquerque, New Mexico.

\subsection{PRESSURE AND GAS GENERATION}

Because the thermal load is less than $20 \%$ of that used in the SARP (SNL 1993) and no gas is generated within the package, the pressure in the package is less than that calculated in the SARP analysis, which was less than the capacity of the package.

\subsection{REFERENCE}

SNL, 1993, Beneficial Uses Shipping System Cask BUSS Safety Analysis Report for Packaging (SARP), Volumes I and II, SAND83-0698 (TTC-0430), Rev. 4, Sandia National Laboratories, Albuquerque, New Mexico. 
HNF-SD-TP-SEP-056 Rev. 0

\subsection{TIEDOWN EVALUATION}

The package will be transported in its normal highway configuration. As a part of this, the cask as secured to a skid, which is permanently attached to the trailer. The skid attachment is inspected annually as a part of routine maintenance. 


\section{DISTRIBUTION SHEET}

\begin{tabular}{|c|c|c|c|c|c|}
\hline \multirow{2}{*}{$\begin{array}{l}\text { To } \\
\text { Distribution }\end{array}$} & \multirow{2}{*}{\multicolumn{3}{|c|}{$\begin{array}{l}\text { From } \\
\text { Packaging Engineering }\end{array}$}} & \multicolumn{2}{|l|}{ Page 1 of 1} \\
\hline & & & & \multicolumn{2}{|c|}{ Date May 20, 1997} \\
\hline \multicolumn{4}{|c|}{ Project Title/Work Order } & \multicolumn{2}{|c|}{ EDT No. 619553} \\
\hline \multicolumn{4}{|c|}{$\begin{array}{l}\text { Safety Evaluation for Packaging (Onsite) Singly Encapsulated } \\
\text { Cesium Chloride Capsules (HNF-SD-TP-SEP-056, Rev. 0) }\end{array}$} & \multicolumn{2}{|l|}{ ECN No. N/A } \\
\hline Name & MSIN & $\begin{array}{l}\text { Text } \\
\text { With All } \\
\text { Attach. }\end{array}$ & Text Only & $\begin{array}{l}\text { Attach./ } \\
\text { Appendix } \\
\text { Only }\end{array}$ & $\begin{array}{l}\text { EDT/ECN } \\
\text { Only }\end{array}$ \\
\hline $\begin{array}{l}\text { D. W. Claussen } \\
\text { R. L.. Clawson } \\
\text { P. C. Ferrell } \\
\text { J. G. Field } \\
\text { C. R. Hoover } \\
\text { D. W. McNally } \\
\text { M. M. Pereira } \\
\text { W. W. Smyth } \\
\text { Central Files }\end{array}$ & $\begin{array}{l}S 7-55 \\
H 1-15 \\
H 1-15 \\
H 1-15 \\
H 1-15 \\
G 1-15 \\
S 6-51 \\
H 1-15 \\
A 3-88\end{array}$ & $\begin{array}{l}x \\
x \\
x \\
x \\
x \\
x \\
x \\
x \\
x\end{array}$ & & & \\
\hline $\begin{array}{l}\text { HNF-SD-TP-SEP-056 Fi1e } \\
\text { P97-002 }\end{array}$ & $\begin{array}{l}H I-15 \\
H I-15\end{array}$ & $x$ & & & $x$ \\
\hline
\end{tabular}

